tory of completely typical white chalk with flints and fossils such as Micraster, Echinocorys, and Porosphaera. This has simply been described as Maestrichtian "calcaires blancs ... à nodules de silex" (Baykal, op. cit., p. 201), but is virtually the same as the familiar Upper Chalk of north-west Europe. This facies appears to have only reached Turkey late in Maestrichtian times. Lower down there are whitish sandy limestones, marly limestones, and some pink limestone reminiscent of the Hunstanton "Red rock". Palaeogeographical maps show the Chalk sea reaching no farther than the Crimea and the Caucasus in a south-easterly direction (e.g. Wills, 1951, Pl. XVIII).

\title{
REFERENCES
}

Ager, D. V., 1956. Summer field meeting in Italy. Proc. Geol. Ass., lxvi, $329-352$.

Baykal, A. F., 1943. La géologie de la région de Şile (Bithynie-Anatolie). Istanbul Univ., Inst. Géol., Pub. no. 12, 166-234.

MCCAllien, W. J., and M. ToKAy, 1951. Sedimentation phenomena of the Cretaceous of the Black Sea region between Zonguldak and Ereğli, Asia Minor. Congr. Géol. Internat., Rept. Sess. XIII (1948), London, 154-164.

WILls, L. J., 1951. A paiaeogeographical atlas of the British Isles and adjacent parts of Europe. London and Glasgow.

IMPERIAL COLLEGE,

LONDON, S.W. 7.

20 th November, 1957.

\section{RECENT MARINE DEPOSITS NEAR BASRAH}

SIR,-I have read with unusual interest the paper by Hudson $e t$ al. (1). Their conclusions support the contentions of Lees and Falcon (2) regarding recent movements within the lower Mesopotamian Plains, and I likewise have reasons for accepting these views (3).

The above authors mention that so far the only evidence for the Hammar Formation north of Basrah is that given by Macfadyen (quoted by Lees and Falcon), who reported marine foraminifera in "alluvium" at Amara, 95 miles N.N.W. of Basrah, occurring at depths of 3 to 35 feet. It is pertinent to refer to recent studies in the vicinity of Najaf, some 220 miles north-east of Basrah and 160 miles due west of Amara.

Beside the Wadi Ruhaimawi, approximately 15 miles W.S.W. of Najaf, a bore-hole was sunk to a total depth of 26 feet. At depths between 23 feet and 25 feet an interesting fauna was found in some brownish silty clays, including Turritella terebra Lamarck (juv.), Retusa inconspicua, Natica sp., Minolia sp., Dentalium sp., Corbula sulculosa, Ostrea sp., and some echinoid plates. On faunistic grounds, therefore, these silty clays correlate well with the Hammar Formation.

The Basrah specimens were found at depths of 13.4 to 34.4 feet below present mean sea level ; the Amara foraminifera from 7 feet above sea level to 28 feet below sea level; the Najaf fauna occurred at elevations of 133.5 of 135.5 feet above present mean sea level. This vertical range of some 170 feet between the southern and northern fossil occurrences is scarcely due solely to vertical land movements, and regional change in sea level doubtless played its role.

Underlying these Recent deposits-and also extensively developed as surface exposures west of Najaf-are gravel beds comprising quartz, flint, and limestone fragments of gravel and pebble size, usually partially embedded in a sandy, clayey, or gypsiferous matrix. These lie on an eroded surface of U. Fars (U. Miocene), and therefore are younger. The gravel beds in places bear a strong lithological and physical similarity to some Dibdibba exposures 
further south. The age of the latter is not precisely known (probably it is Pliocene) and no fossils have so far been found in the gravels, but the possibility of correlating the two is tempting.

Should further work substantiate these findings and suggestions, then we may postulate Recent marine transgression extending as far as the Najaf area-almost halfway up the present delta.

Alwiyah Club,

BAGHDAD, IRAQ.

28 th November, 1957.

\section{REFERENCES}

(1) Hudson, R. G. S., F. E. Eames, and G. L. Wilkins, 1957. The Fauna of Some Recent Marine Deposits Near Basrah, Iraq. Geol. Mag., xciv, 393-401.

(2) LeEs, G. M., and N. L. FALCON, 1952. The Geographical History of the Mesopotamian Plains. Geogr. Journ., cxviii, 24-39.

(3) Mrtchell, R. C. (In press.) Recent Tectonic Movements in the Mesopotamian Plains. Geogr. Journ.

Raoul C. Mitchell.

\section{NAMURIAN STAGE NAMES}

SiR,--In a recent paper Dr. F. Hodson (1957) has most usefully discussed and correlated the various faunal bands occurring in the West European Namurian in the lower part $\left(R_{1} a\right)$ of the Kinderscoutian Stage and the upper part (Ha) of the Sabdenian Stage, and redescribed and figured some of the goniatites that occur therein. He has also proposed the replacement of the well-established Namurian stage Sabdenian (Homoceras Age, $\mathrm{H}$ ) by two stages: an upper one which he equates with the Homoceras eostriolatum zone $(\mathrm{Hb})$, the upper zone of the Sabdenian, and names Alportian; and a lower one which he equates with the $H$. beyrichianum zone (Ha), the lower zone of the Sabdenian, and names Chokierian. The stage names used for the Namurian before the publication of Dr. Hodson's paper have been accepted and widely used since their erection in their current form by Hudson and Cotton (1943). If chaos is to be avoided, changes in the nomenclature of stages should only be accepted for the most cogent of reasons, and it is, therefore, surprising to find that no reasons for his proposed changes are given by Dr. Hodson in his paper.

The name Sabdenian (founded Bisat, 1928, p. 126; redefined Hudson and Cotton, 1943, p. 152) was based on the formation Sabden Shales. The type section of the upper part of the Homoceras age was chosen by Bisat $(1924$, p. 49) as that exposed at Roughlee, east of Pendle Hill, Lancashire. There in the upper part of the Sabden Shales all the faunal bands typical of the upper zone $(\mathrm{Hb})$ of the Sabdenian are exposed (Bisat, 1924, p. 49 ; Bisat and Hudson, 1943, p. 399 ; Hodson, 1957, p. 14). The change in the name of the upper part of the Sabdenian to Alportian also carries the implication that rocks of this age are well exposed at Alport in Derbyshire, which will become the typical sections for beds of this age. The exposures in Alport Dale, however, are incontestably worse than those at Roughlee.

There may be better reasons for using sections in the Assise de Chokier as typical of the lower part of the Sabdenian, but even in this case the biostratigraphical succession can be demonstrated in the Sabden Shales in Lancashire, and a change seems unnecessary.

It therefore seems to us that Dr. Hodson's proposed changes are unnecessary and even retrograde, and that the Sabdenian should be retained as a stage name within the Namurian. 